\title{
WHY NOT FORM A PLAYREADING SOCIETY
}

With the foundation of the National Theatre in South Africa, one hears a good deal of speculation about the future of drama in this country. It is obvious that everyone cannot be a successful actor or actress, but it is not generally realised that almost everyone can enjoy the reading of plays.

For a national drama to succeed in the fullest sense, the nation itself must be deeply interested in drama, as happened in England in Elizabethan times. Merely to legislate from above and be satisfied to leave it at that, will be to base our South African dramatic edifice on insecure foundations; whereas to encourage everywhere in South Africa the formation of small societies interested in plays will be to build soundly by helping to develop a love of drama among the people themselves.

Hence I urge all those interested in dramatic activity to form small playreading groups in their own village, town, or city. To found and organise a playreading society is not nearly as difficult as it may sound; it is, like so much else, a question of sound administration and hard work, and the results are well worth the trouble.

That such an idea is practicable the experience of various societies of this kind in South Africa goes clearly to show. Let me quote from my own experience as President of our Playreading Society in Potchefstroom. There are doubtless other ways just as good of organising a cultural group 
of this sort; I give details of the methods we adopt, in the hope of assisting those who have no experience of such things but are interested in founding a similar society of their own.

Three years ago we began with nothing but the enthusiasm of some half-dozen people to back us. We founded our Society with the aim of encouraging an interest in English Drama, particularly in modern English plays, and applied for affiliation to the Federation of Amateur Theatrical Societies of Southern Africa. The subscription is a guinea annually, and membership gives a society the privilege of making use of the well-equipped Bloemfontein Drama Library for the sum of $7 / 6 \mathrm{~d}$ a year.

As soon as copies of the play required are received from Bloemfontein, the Secretary gives each member of the Committee a copy, and a committee meeting is held a day or so later at which the play is discussed and the cast selected. Those reading parts are then provided with a copy of the play and a list of those playing opposite them, and all members are reminded of the date and venue of the following meeting.

Our Playreading Society meets every alternate Wednesday night in term time, many of our members being engaged in the teaching profession. We thus manage to hold some fifteen meetings during the year. These take place in the houses of various members, and a friendly, informal atmosphere is engendered. The ideal arrangement is that of two interleading rooms, in one of which an acted playreading can be staged, and in the other of which those not taking part can sit and watch. To hire a hall for these occasions is both unnecessarily expensive and detrimental to the informal atmosphere in which playreadings really flourish.

Our subscription is five shillings per annum, and with a fair credit balance after three years' working we see no reason to increase it. It works out at fourpence per meeting, during which a three-act play is read and after which lady members of the Society take turns in providing tea.

Each meeting begins with the reading of the minutes of the previous meeting. The reading and signing of this brief report is a little formality designed to keep as full a record as possible of the doings of the Society and to remind members that its affairs are managed in an organised and not merely haphazard way.

Then follows a short introduction to the play to be read that evening, prepared and read by a member of the Committee or by an ordinaty member previously invited to do so. This brief introduction is only necessary on occassion, particularly when the play to be read is one of literary or historic interest, and serves to acquaint those present with any information thought necessary to a better understanding of the play itself. If the importance of the playwright warrants it, something may be said of his achievement, influence, and position in English Drama. 
Stage directions, to enable the audience better to visualise for itself the scene of the action, and details of the casting are always given before the reading begins, either by the member responsible for the introductory talk or by the President in his capacity as master of ceremonies.

It is important that the playreading should always be an acted one. Drama implies action, and to sit round a table and merely to read, even if each of those taking part has a copy of the play, is to defeat the object of drama. There must be action, movement, and dramatic life in a playreading.

Hence readers should be encouraged to move easily about the room, enter by the right entrances, leave by the right exits, and make use of gesture and facial expression whenever necessary to reinforce the spoken word. It will be found that readers soon develop confidence, resourcefulness, and a sense of position by this means.

Before beginning the reading, those taking part should agree among themselves as to the pieces of furniture in the room that are to represent the furniture on the stage, and keep to their decision. After a little experience of this kind, it is possible for a cast to read a play extempore. With a difficult play a rehearsal is necessary.

It may be urged that even acted playreadings of this kind leave too much to the imagination of the audience, there being no scenery and few stage properties. Against this view, however, I maintain that such a type of dramatic activity enables a really keen listener to derive ,not less, but more, from the play. Nothing ever appears the same to two different people, and in an acted playreading everyone is free to supply the necessary background from his own experience and mental resources.

Naturally a certain degree of imagination is expected from the audience, all of whom must be prepared to grant what Coleridge termed 'that willing suspension of disbelief for the moment ehich constitutes poetic faith'. the Elizabethan stage with its lack of scenery and curtains, its proximity of actors to audience, its crude 'props' an contemporary dress convention, showed well what could be achieved by such means.

The advantages of playreading over production may briefly be mentioned. It is naturally not my aim to discourag $z$ the production of plays by amateurs, which deserves all the encouragement it can get in a country whose cultural interests seem sometimes to be bounded entirely by the film. My aim is rather to show that the average man end woman can, with the help of friends and others of similar tastes, enjoy the pleasures of dramatic activity and derive its many benefits by means of playreading in a regular, inexpensive, and practical way. To produce a play requires much time, a certain amount of capital, and a good deal of risk. Further, production cannot frequently 
be undertaken by any one society, unless its resources be unus'sally large. Apart from the cultural value of playreadihg, the direct benefit to speech is worth considering. Gesture and movement must naturally be restricted by the necessity of carrying one's book around the room, but much more can be done by means of the voice than is generally thought. A good reader, by altering his pitch and tone, can express almost anything he wishes. This flexibility of utterance is one of the most valuable qualities a man or a woman can possess; and though some fortunate people are naturally gifted in this derection. much may be done by intelligent application.

Playreading is among the most pleasant ways of improving one's spoken English (or Afrikaans), and should appeal to all those who are desirous, not only of making the voice the expression of the personality, but also of improving their command of language and their ability to use it as an instrument of thought.

The question of dialect worries some people who would otherwise be interested in reading plays together. Here I feel that unless the dialect is essential to the play, as in the Irish plays of J. M. Synge, it may safely be ignored. Bad dialect is worse than useless; it is much better to read normally and leave dialectal niceties to the experts. Besides, very few SouthAfrican audiences can distinguish between any dialects in English except the very broadest.

Those with whom I have discussed playreading in the large cities of the Union have sometimes said: 'Yes, I agree with you, and I wish I was there to take part in your readings; but in a big town like this it's quite different.' With this I have never found myself in agreement. The membership of a playreading society is limited. I should say that about thirty people, which is our own membership at the moment, constitutes its maximum. There is the matter of accommodation: not many lounges in private houses will hold more. If the venture should prove a success, and there be a consequent overflow, another playreading society may be establiched and run on similar lines.

If you are interested in this idea of playreading, call a meeting of people of similar cultural tastes, elect a responsible committee of five (President/ Chairman, his or her deputy, Secretary/Treasurer, and two additional members), and make the first three an executive committee with full powers. Should you decide that membership be more than $5 /-$, a fund may be built up for the purchase of plays.

And remember that any playreading society worth the name makes a point of regular meetings. We have found that twice a month during term time is the best arrangement; once a week is too often, once in three weeks too seldom. The Comittee meets oftener, for allocation of parts and choice of the next play to be read. 
Lastly, make a firm resolve that never will your Society miss a meeting that is due to be held. Nothing kills the enthusiasm of members so quickly as to find that meetings are in the habit of being postponed or cancelled at short notice.

The future of Drama in South Africa, as I said at the beginning of this article, depends on its people. So what about forming that Playreading Society of your own?

Potchefstroom.

R. E. Davies. 